\title{
Autonomy Of The Algerian Central Bank In The Era Of Economic Reforms (A Normative Juridical Study Of Monetary And Credit Law)
}

\author{
Dr. Bakhouya Driss, Associate Prof. \\ Faculty of Law and Political Science, University of Adrar, Algeria
}

doi: 10.19044/esj.2016.v12n13p434 URL:http://dx.doi.org/10.19044/esj.2016.v12n13p434

\begin{abstract}
Globalization brings new challenges to the Algerian government. This issue implies a serious establishment of a domestic and a foreign economic stability in an attempt to confront the changes of the new economic wave. One of the reform requirements in this context is represented by the independent policy of the central banks. This consideration stems from the crucial role played by this institution in the economy (regulation of the money supply, organization of credits...). Algeria for instance embarked on this line of reform via various laws and jurisdictions. The study sheds light on the autonomy of the Algerian central bank through the law No. 03/11 in connection with the Monetary and Credit Law.

The study states that the independence of the central and is a pivotal condition to increase the performance of the banking institutions in Algeria. The second point is that this autonomous policy of the central bank leads inevitably to a stabilization of the financial and economic indices of the country.
\end{abstract}

Keywords: Globalization, Monetary authority, autonomy, central bank, economic reforms.

\section{Introduction}

One of the purposes of the development of the economic activities is to increase the level and the quality of the products and services presented to the society. This aim is the result of the interaction of different economic agents who are distinguished in their capabilities of production and their needs and requirements. (Ahmed Henni, 1997: 18).

The contribution to increasing the social and economic welfare is ensured by works and skills of the economic circle parts. The bank of generally the financial institution is one of these important agents as it manages the circulation of payments means which are vital to increase the flexibility of 
the economy. The history mentions that the bank has been existed for more than two centuries ago, but the institution framework had not seen the light till the $19^{\text {th }}$ century. As examples of the first central banks: the Riks Bank in Sweden (1868), England Central Bank (1894) which was a supreme body to handle the financial issues, French Central Bank, Germany Central Bank (1876), Holland Bank (1814), Norway Bank (1817), Danish bank (1818), Belgium Bank (1850), Spanish Bank (1856), Japan Bank (1882) which played great role in stabilizing the Asian currencies values.

In $19^{\text {th }}$ century many central banks all around the world had been founded: in Portugal, Rumania, Bulgaria, Serbia, Turkey, Java and Egypt. At the end of $19^{\text {th }}$ century European countries had also founded different central banks. Many eastern countries, such as India and China at that time did not have a central bank, In America, the first central bank that was founded was Federal Bank in 1913 and Canada Bank in the late 1934 (Diya'a Majid Almousaoui, 1993: 243).

The main factor behind the establishment of the central bank was the international finance conference held in Brussels Belgium in 1920. This conference approved that all countries must establish their own central banks as a supreme body to run the financial and economical issues. These issues are represented by the aim of the financial stability and the support of the international cooperation. (Kock A. G, 1987: 19). As the result of that conference, many countries founded their central banks. Some countries in Asia, Africa, and South America established this institution just after their independence by the support of IMF as an international organization.

\section{Research Problems:}

Based on the background of the study above, the research problems of this study can be stated as follows:

1. How the Algerian banking law paves the way to the independence of the Algerian central bank?

2. What is suitable type of the central bank independence to the future Algerian economic reforms?

\section{Research method:}

This research is a juridical and normative study in which different regulations and laws of finance and credit in Algeria are represented. The study adopts also principles of justice as a parameter in conceiving a solution to the issues cited above.

In this context, the basic concern remains to analyze the jurisdictional interactions between different law and regulation related to finance and credit. The economic reforms are drafted and projected by various laws such as: law of Republic Algeria No. 03/11, law No. 10/04 about Monetary and 
Credit especially sections $01,10,42$, and section 58 . These sections illustrate the structure and the responsibility of the Algerian central bank. The method adopted to analyze the autonomy of the central bank is the normative philosophical approach by which different laws and regulations and presented and interpreted. Indeed, the research sheds light on the principles of reforms in regulating and arranging the credit market and the financial system as well as the conditions to set and independent central bank.

\section{THEORETICAL FRAMEWORK:}

The main target of Central Bank all over the world is to maintain the stability of currency and to get the ideal rate of economic growth. This target would not be achieved if the authority of Central Bank is restricted in its functions by the government interests and considered just an institution to provide funds and fulfill the insufficiency of governmental budget. Such condition can create inflation and budget deficit which lead to a hard currency depreciation. In this field of thought, the failure of the state' financial management represents a primary requirement for establishing the autonomy of the central bank. This policy of the central bank management leads to a sound and well structured financial system in which the goal of the currency stabilization could be ensured.

\section{A. Theory of Classical Freedom Philosophy ( John Maynard Keynes):}

Before Keynes (1883-1946), Classical Economics assumed that the economic system is able to exploit fully the production factors (capital, labor, land and management) in order to achieve the suitable level of production necessary to satisfy the individuals' needs. As the result, all classic economists convinced that recession happened in the world would be improved automatically (natural law) as the falling of interest rate along with the increasing of the saving rate will push all entrepreneurs to increase their borrowing and conduct investment. In addition to this, the falling of the wage rate will decrease the costs and push all entrepreneurs to estimate the big number of labor. The attention of Keynes toward depression as the effect of endless and wide world forces led him to find another explanation about recession (Souhair Mahmoud Maatouk, 1998: 172).

\section{B. The Monetary Theory of Chicago (Milton Friedman):}

Milton Friedman (1912-2006) opposed the Keynesian government policy in terms of repairing aggregate demand. In this context, he argued that this policy emphasized the uncertainty and resulted unstable economics. Instead, he suggested that government could increase money supply gradually (Money Supply) at the same level with long term improvement in the national output. This economic process is capable to reduce the inflation 
rate. In an economics experiencing high inflation rate, Friedman argued that the sharp degradation in growth level of the money supply decreases the demand level and creates a big number of unemployment. However, he argued that the increasing of unemployment is temporary as it is conducted by the society expectation of the inflation rate in the future. This situation serves inevitably the full exploitation of the production factors. Friedman Monetary stream had been a subject of a wider adoption especially during the 1980s.

About the relation between the consumption and earning, Friedman rejected the Keynesian idea stating that the improvement of society earnings will be ensured and expanded when the saving rate is bigger. Additionally, he argued that the consumption is a constant fraction from the permanent consumer income even at the long term when the correlation between the consumption and the income is stable.

According to this theory, the governmental pressure upon the financial institution, especially the Central Bank, intensifies budget inflation and yields the economic instability. The Maastricht convention about financial and economical principles of European Union states two principles to deal with difficulties of the financial system. These conditions are: 1 . stability of price, 2. completing the central bank autonomy.

Bade and Perkin conducted a research in their book entitled "Policy of Central Bank and Monetary Politics”. The research analyzed between central bank and government in 1944 between 12 states: United States, Britain, Germany, Japan, French, Italian, Canada, Switzerland, Australia, Sweden, Belgium and Denmark. The results of the comparison are the followings:

(1) Level of pressure influence conducted by government to the Central Bank, (2) governmental ability to give salary to the Central Bank members, (3) governmental ability to arrange bank ability, (4) governmental authority to select and recruit Central Bank members.

According to Friedman, inflation is a financial phenomenon caused by a larger growth of money relatively with the national output. Therefore, inflation is considered as the result of more currency issuance conducted by other considerations (social, political or merely economical considerations)

\section{LITERATURE REVIEW:}

\section{Studies about the relation between Central Bank, Inflation Rate and Budget Failure;}

The inflation crisis of 1970s had forced all economists to conduct studies in an attempt to determine the relation between the increases of inflation rate and the influence of political pressure on central bank.

The results of the study are as follows (Ausama Alfouli, \& Majedi Sihab, 1999: 245): 
a. Study of R. Bade, and M. Perkin (1985): is the first study about relation between autonomy of central bank, the governmental intervention and inflation rate stability. This study measures autonomy of central bank by the following factors:

1. Range of government influence on central bank monetary measured by government role in determining salary of central bank councilors, and the central bank members.

2. Rate of government influence on central bank politics measured by government role in improving councilor of central bank administration, and by government representatives in this council.

The results of the study of R. Bade, and M. Perkin (1985), show that the autonomy level of monetary aggregates had not been considered as an influencing factor of the inflation after period of Bretton Woods. At the other side, the autonomy in determining the financial politics is the important measurement of the inflation factor. The facts can be seen in Germany and Switzerland states where their central banks had the full autonomy authority in determining monetary politics, the inflation rate in both countries is the lowest compared to rest of the world (Ali Toufik Sadek, Husni M, 1997: 158).

b. Study of A. Alesina (1988): This study tracks the same line as the previous one in which the results show an inverse relation between the autonomy of the central banks and the inflation rate.

c. Study of V.G. Rilli, D. Masciandara, and G. Tabellini (1991): This study adopts two other factors to measure the autonomy of central bank which are:

1) The political factor: the same with Bade \& Park's study.

2) The economical Factor: This factor measures the autonomy of the central bank through government rights in determining the conditions allowing the government to get credit from central bank at one hand: at the other, the factor analyzes the autonomy via the government rights towards the monetary authority figured out by the central bank.

The result of this study is that there is an inverse relation between autonomy of central bank and inflation rate. This issue means that the higher central bank autonomy is associated with the lower inflation rate, and vice versa (lower central bank autonomy is linked by a high inflation rate).

\section{Relation between Autonomy of Central Bank with Stability of Price as the main target of the Monetary Politics;}

Central bank as regulator institution of monetary issues aims at stabilizing the prices as the main target. The latter is not achieved without the full freedom, power and discretion of the central bank. This consideration is based upon the following criteria: 
a. Monetary policy is the only responsible and appropriate institution of to perform the function of keeping the price stability compared to other economic functions.

b. If the monetary policy of central bank covers some different targets which are related to the balance payment and growth, so in this situation the central bank will be responsible to deal with the government matters.

c. Generally, the monetary policy targets are to reduce the transparency and to weaken the responsibility of central bank and its managers.

d. Mostly, the monetary politic targets performed by the central bank will reduce the trust, where this trust is the main ideal concept of central bank.

Although the results of the study about the relation between autonomy levels of central bank with the decrease of inflation rate show positive consequences, there are a lot of criticisms addressed to the supporters of autonomy of central bank, some of them are:

a. There is no appropriate instrument to measure the autonomy level of central bank - besides Zukerman's studies considered as best studies in this field - The absence of an appropriate measure to examine the banking legislation leads to an unavoidable lack in determining correctly the autonomy of the central bank (Ausama Alfouli, \& Majed Shihab, 1999: 253).

b. Those studies are conducted based on legislation, but in fact there is difference between autonomy of central bank in legislation and autonomy in practice, the fact that lets the result of the study imprecise and ambiguous.

c. Measure of theory about autonomy of central bank have subjective character and tends to prove that autonomy of central bank decreases the inflation rate.

B. The Common Picture of the Law No. 10/04 about Money and Credit;

The Law No.10/04 distinguishes between two periods of economic systems in Algeria. That situation is the change of central economic system changing into market economics period. This circumstance was a result of state's situation in; democracy experience which just run for 1 year, the decrease of world oil price, and the greater debt of the state. Therefore, state attention focused on:

1. Overcoming sociological problems based on development of work relation and the reformation of education and health institution.

2. Passing the laws on financial clearance and eliminate the inflation (Mohammed Elfnish, 2000: 148). 
The Publishing of the Law No.10/04, as a result of the economic reforms, especially the monetary which aimed to change the central economic system into a market one.

\section{Monetary Political Principles after Reformation of the Law No. 10/04;}

The law covers some principles mentioned in Law 1986 and 1988. But this Law creates new principles related to banking organization. The principles are:

\section{a. Monetary Authority Autonomy;}

Monetary Authority Autonomy is a monetary decision decided by a monetary institution which is taken separately from government interference. This policy has the following purposes:

1. To bring back the authority of banking institute to organize monetary and credit.

2. To bring back the money currency of diner of Algeria as a means of measurer to all decisions in monetary.

3. To create distinguished system between central bank as money publisher and commercial bank as credit provider institution.

4. To rebuild the money market effectively (Attahar Latrash, 2003: 196).

That is why, that decision is taken based on the monetary situation determined by the monetary institution.

a. Function of the Monetary and Credit council based on the Law No. 10/04:

Council of Monetary and Credit has the status as a monetary authority by (Mahfouz Laachab, 2006: 56):

1) Issuing money based on section 4-5 of this law.

2) Arranging transaction organized by central bank, especially relating to properties and currency.

3) Determining and arranging state's monetary policies.

4) Performing clearing.

5) Regulating payment tools.

6) Determining requirements to open banks and monetary institutions as well as branches.

7) Determining requirements to open monetary institutions and foreign banks in Algeria.

8) Giving protection to the clients of the bank and the monetary institution.

9) Publishing regulations about finance market (Mabrouk Housin, 2004: 08).

Council of monetary and credits may take the following decisions:

1) Permission to establish banks and financial institutions.

2) Permission to establish foreign bank branches in Algeria. 
This monetary council has to cooperate with government especially with the ministry of finance in an attempt to give the suitable information to governmental body. Governor has to submit regulations of banking to the finance Minister. The latter in his right has a discretionary authority for 10 days to ask changes of the regulation. The governor has to inform councilor for change in 5 days. After that, the decision taken by council of monetary and credits can be performed directly, and published in official journal of the state (section 64).

\section{b. Central Bank Observation:}

The supervision imposed on the central bank is conducted by a commission consisted of two controllers appointed by the commission chairman. Two of these controllers must have high experience especially in finance and banking accounting. Authority of this Commission is determined by administration council.

This commission lays observation in general to the instrument of central bank and to the central risk body of the financial market in particular. These two controllers assume their responsibilities separately or collectively. They also can attend administration council conferences as advisers. These Commission members can give observations and suggestions needed to the council. If this suggestion is refused, they can note it in the council suggestion list, and submit their suggestions to the finance minister (section 27 articles 3 ).

This commission has to submit financial report for 4 months after the closure of the accounting period. Governor can accept copy from the report. Finance Minister can ask report from this commission according to certain situations and problems.

\section{c. The Authority of the President on the Governor;}

President can accept report about all the central bank activities, annual result, bank transaction, and supervising to conventional bank. This report is published in official journal of state after 1 month. Governor has to send report routinely to the president and the council of money and credit as an assessment to his activity in central bank structure.

Governor also has to send other documents as follows:

a. Report about the state of deposit.

b. Report on the foreign debts' state and liquidation level to pay the debt (Mabrouk Housin, 2004: 23).

Algeria Bank has to publish report about economic growth and the state's finance, followed by a clarification to the parliament.

\section{d. Authority of the Bank of Algeria:}

Central bank of Algeria based on the Law No.10/04 has a general authority in credit and money. It assumes the responsibility of the economic growth, and the internal and external monetary stability. Therefore, it is also 
given the authority to arrange the monetary policies, credit division, and the financial market. In this field, the government has to consider more cautiously the opinions of central bank about all legislations and regulation plans related to the monetary aggregates.

Bank of Algeria assists and enhances the government position in relation with the international monetary institution, and represents the government at the international bodies and conferences. It also conducts the discussions about conventions and agreements signed between the government and the international monetary institutions and ensure the performance of these meetings. Central bank also has authority as a money issuer, based on the requirements and the conditions determined in section 62 as follow:

a. Central bank can give credit within one year to a conventional bank, with gold and foreign currency as guarantee.

b. Central bank in rule of the council of monetary and credits can do transaction named:” Open Market Politics” to keep the stability between inflation and deflation.

c. Central bank can give credit to treasury within 240 days, based on basis of agreement between treasury and central bank.

d. Bank of Algeria performs all monetary transactions with another bank, monetary institution, and foreign bank.

e. Bank of Algeria performs clearing (Section 62 article 1, Law No.10/04).

\section{CONCLUSION}

Algeria has tried to build authority of finance since the publishing of the Law No.03/11 about Money and Credit. This law includes important principles in the field of autonomy of finances authority in Algeria, since economic studies practically proved positive influences on the autonomy of the financial authority of some countries in the world like the financial policy of German bank.

Changes regulating the financial system in the world are generally related to the economic strength like the different stock exchanges of Wall street, London, and Tokyo. However, Algerian stock exchange has been built based on laws, the case which proved the weaknesses of economic actives.

However, the existence of the Law No.10/04 about Monetary and Credit brought negative step on autonomy of political finance in Algeria. Especially in section which is contradict to the relationship between central bank and government.

Overall, it can be concluded that:

1. Autonomy of Algerian Central Bank based on the legislation of banking cannot be measured with certain factors, but variously as according to the elements explained in the previous chapters. This autonomy is the ability of Algerian Bank to determine politics of finance based on the 
permit given by laws without any pressures from government or parliament.

2. It is difficult to reach high level of autonomy in Algeria, since currency is used as a means of economy. This currency also represents a political presence. It had proved that the autonomy of central bank was predicted to diminish after the publishing of the Law No.10/04 about Money and Credit. This issue is caused by a government intervention in the Algerian bank; hence the autonomous form can stabilize price and assess currency”. Through this autonomy of central bank policy, this institution can protect itself from any political pressures conducted by executive power from one side, and through full freedom to execute politics of finance from another side”.

\section{RECOMMENDATIONS}

The recovery process move slowly. The reason behind this is the complexity level of problems' scale. The latter is faced by the effect of the imbalance in banking sector and so many unstable banks. With such conditions, the restructuring program of banking in Algeria requires complicated and long preparation, tight coordination, and also high expenses and the fragile national Banking condition as the effect of various internal weaknesses. The situation is progressively made worse by external pressure such as: uncertainty of political condition. At this point, the following suggestions are presented:

1. Government of Algeria should return to the autonomous principles of central bank drafted in the Law No.03/11. This application allows to maintain economics of the country, stabilize financial system in general and stabilize price and currency. These targets lead inevitably to a new wave of economic information, and also the network system for better communication. The central decision in its turn is able to face all constraints hindering its function as according to external commercial needs and investment.

2. To reach autonomy which can stabilize price and assess currency, the important thing to do is the harmonization with other related government agencies especially finance department. At this point, it is becoming a necessity if finance management and monetary in Algeria want to perform the job properly .Therefore the Algerian government has to take the following steps: 1) Developing human resource to get best in the field of banking transaction. 2) Overcoming corruption problem in financial system by strengthening the structure of banking supervising institution. So that the central bank is able to handle conventional banks, especially the private banks. 3) Providing more chances for private banks to take part in government program so that they can play many 
roles in economics reformation programs that are handled by government. 4) Applying regulations which can determine the functions authorities of central bank independent from government intervention in order to reach real autonomy.

\section{References:}

A. G. kock. (1987). Central Bank. Translation; Abdelwahad Almakhzoumi, Beirut. Lebanon.

Ahmed Henni. (1997). Currency and Finance, Ben Aknoun, Algeria.

Alfouli Ausama, \& Mahmoud Shihab. (1999). Principles of Finance and Banking, Dar Aljamia’a Aljadida, Egypt.

Atouan Merwan. (1993). Monetary Market and Finance. (Stock Exchange and the Problem in Monetary Area) OPU, Ben Aknoun, Algeria.

Diya’a Majid Almousaoui. (1993). Banking Economic; Theory Regulation, Financial Institution. Dar Elfiker. Algeria.

Elfnish Mohammed. (2000). Financial Sector in Arab Countries. Arab monetary fund. Abu Dhabi. Emirates.

Housin Mabrouk. (2004). Money and Finance in Algeria (Algeria Bank, Observation Commission, treasury, and assurance). Dar Houma. Algeria.

Latrash Attahar. (2003). Technique of Banking. OPU. Ben Aknoun. Algeria. Maatouk Souhair Mahmoud. (1998). New Thoughts from Modern Economists. Cairo. Egypt.

Mahfouz Laachab. The Law of Banking. OPU. Ben Aknoun. Algeria.

Sadak Ali Toufik, Husni M, \& Nabil A., (1997). Politic and Exchange Price in Arab Countries. Arab monetary fund. Abu Dhabi. Emirates.

Laws:

Order No.10 / 04 about Monetary and Credit.

Order No.11 / 2003 about Monetary and Credit.

Regulation No.01/2000 regulates the credit and central bank toward commercial banks and financial institutions. 